\title{
Past and present platinum contamination of a major European fluvial-estuarine system: Insights from river sediments and estuarine oysters
}

\author{
Abdou M. ${ }^{1}$, Schäfer J. ${ }^{1,}$, Cobelo-García A. ${ }^{2}$, Neira P. ${ }^{2}$, Petit J.C.J. ${ }^{1}$, Auger Dominique ${ }^{3}$, \\ Chiffoleau Jean-Francois ${ }^{3}$, Blanc Gerard ${ }^{3}$
}

${ }^{1}$ Université de Bordeaux, UMR EPOC 5805, TGM team, 33615 Pessac, France

${ }^{2}$ Instituto de Investigacións Mariñas (IIM-CSIC), Vigo, Galicia, Spain

${ }^{3}$ IFREMER, Centre Atlantique, BP 21105, F-44311 Nantes Cedex 03, France

*Corresponding author : email address : jorg.schafer@u-bordeaux.fr

melina.abdou@u-bordeaux.fr ; acobelo@iim.csic.es ; pneira@iim.csic.es ; jcjpetit@gmail.com ; Jean.Francois.Chiffoleau@ifremer.fr ; gerard.blanc@u-bordeaux.fr

\begin{abstract}
:
Platinum Group Metals (PGM) are modern, technologically relevant elements for which (i) the anthropogenic cycle has outcompeted the natural cycles and (ii) environmental behavior, fate and impact are still widely unknown. Stripping voltammetry was used for accurate determinations of platinum $(\mathrm{Pt})$ in historical records of river sediments and estuarine oysters from the Gironde fluvial-estuarine continuum (SW France) comprising the Lot River. Sediment cores from the Lot River, dated from 1952 to 2001, showed past Pt contamination due to former industrial (smelter) activities in the Lot River watershed. These samples revealed the phasing-out of a historical $\mathrm{Pt}$ contamination with $\mathrm{Pt} / \mathrm{Th}$ (Thorium) values of $11 \times 10-5 \pm 0.79 \times 10-5$ for the deepest part of the core which is clearly greater than the regional geochemical background value (Pt/Th $\sim 2.2 \times 10-5 \pm 0.68 \times 10-5)$. Wild oyster samples from the mouth of the Gironde Estuary collected from 1981 to 2013 showed Pt concentrations ranging from $0.80 \pm 0.01$ pmol.g- 1 to $3.10 \pm 0.14$ pmol.g- 1 . Oyster samples have recorded the phasing-out of the smelter-related historical industrial $\mathrm{Pt}$ contamination and empirical modelling suggests the recent rise of a new source of $\mathrm{Pt}$ to the system. Temporal variations of $\mathrm{Pt}$ in oysters attributed to this recent source reflect the exponential increase of Pt demand for car catalytic converters, pointing towards the increasing importance of this emerging source to the aquatic system. Estuarine oysters prove to be suitable bioindicators for Pt contamination providing sensitive monitoring of emission variations over time. Furthermore, oysters may bioconcentrate Pt (Bioconcentration Factor, $\mathrm{BCF} \sim 103$ ) and transfer this metal contamination to the higher food chain. These findings highlight the need for a deeper understanding of environmental Pt contamination, processes and possible adverse effects to biota.
\end{abstract}




\section{Graphical abstract}

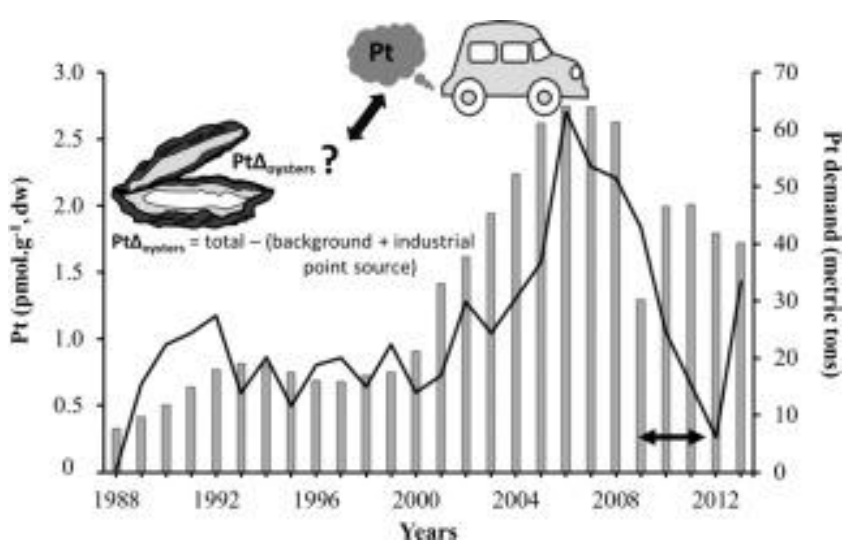

\section{Highlights}

- Historical Pt records reflect past and present anthropogenic sources. Wild oysters are sensitive biomonitors of Pt contamination that bioconcentrate Pt. Anthropogenic Pt emissions may profoundly affect $\mathrm{Pt}$ budget of the watershed.

Keywords : Platinum, sediments, wild oysters, bioaccumulation 


\section{INTRODUCTION}

Platinum $(\mathrm{Pt})$, one of the rarest elements in the Earth's crust with a typical concentration of 2.6 pmol.g ${ }^{-1}$ (Rudnick and Gao, 2003), is a strategic commodity for industries in many countries (Reith et al., 2014, Cobelo-García et al., 2015) since its physical (density, resistance to corrosion) and chemical (e.g. catalyst) properties serve in many applications such as laboratory and medical equipment or (medical) drugs. The most extended application is the use of Pt-based vehicle catalytic converters which contain about $1.5 \mathrm{~g}$ of $\mathrm{Pt}$ (Zereini et al., 1997) representing more than 70\% of the total European Pt demand in 2013 (Johnson Matthey, 2014). Therefore these devices are recognized as a major source of Pt to the environment and together with the burning of fossil fuels, mining and other industrial uses has led to a complete disturbance of the global Pt cycle (Sen and Peucker-Ehrenbrink, 2012). The significant recent increase of Pt concentrations in Antarctic snow (Soyol-Erdene et al., 2011) suggests large-scale atmospheric transport of Pt (Barbante et al., 2001) implying its global contamination. Major concerns on ecosystems and biota contamination arose few years after introducing car catalyst technology in Europe (e.g. Schäfer et al., 1999) and today anthropogenic Pt enrichment is recorded in all Earth compartments: atmosphere, water, sediments, and soils (e.g. Pawlak et al., 2014). Accordingly, Pt is considered an "emerging pollutant" for which it is necessary to develop innovative techniques providing reliable quantitative estimates of environmental pathways, loads, and concentrations (Rodrigues et al., 2009). To date, however, there is still a lack of data on environmental Pt concentrations mostly due to the relative difficulty to measure this element at low ambient levels. Recent work on Pt behavior in the Gironde Estuary has shown that estuarine reactivity along the salinity gradient is crucial for both the Pt distribution in the estuary and dissolved Pt export to the global ocean (Cobelo-García et al., 2014a). The net dissolved Pt addition due to estuarine mixing results in a higher export of dissolved Pt to the ocean than expected from the riverine input (Cobelo-García et al., 2014a). However, Pt sources and possible contamination of this system are still unknown. The present work aims at identifying past and present $\mathrm{Pt}$ contamination and sources by combining the first historical records of $\mathrm{Pt}$ in river sediments and estuarine oysters from the Gironde fluvial-estuarine system. 


\section{MATERIAL AND METHODS}

\subsection{Study area}

The Gironde Estuary (about $170 \mathrm{~km}$ in length), draining a $80000 \mathrm{~km}^{2}$ watershed, is a major European estuary considered a model for physical, hydrological and geochemical studies especially on trace element transport and reactivity in impacted watersheds (e.g. Lanceleur et al., 2011). The Lot-Garonne-Gironde fluvial-estuarine system is affected by multi metal pollution originating from a common main point source being a former Zn-ore mining/metallurgic industry (e.g. 1842-1987: Cd, Zn, Cu, Pb; Audry et al., 2004a) on the Riou-Mort River near Decazeville (Figure 1). After transport, trace metals can settle down and be deposited in river sediments where they accumulate under favorable hydraulic conditions provided by natural and reservoir lakes (Audry et al., 2004a). In 2001, two continuous sediment cores of about 1.4 m-long were collected using a manual corer consisting of a 10x10 $\mathrm{cm}$ rectangular Plexiglas tube. Sampling was realized in two hydroelectric reservoirs of the Lot River: the reservoirs of Marcenac and Cajarc located respectively upstream and downstream the Riou-Mort River i.e. the hypothetical Pt pollution source (Figure 1). The sediment cores were sliced in thin horizontal sections at $1 \mathrm{~cm}$ resolution from the surface to $25 \mathrm{~cm}$. The lower part was sampled with a $5 \mathrm{~cm}$ resolution. Immediately after recovery, each sliced section was centrifuged in order to remove pore waters and then sealed in sampling-bags under nitrogen. Sediment samples were dried at $50^{\circ} \mathrm{C}$ to constant weight and then powdered and homogenized with an agate mortar (Audry et al., 2004a). The second set of samples consisted of a historic series of wild oysters which, as suspension feeders, are exposed to both dissolved metals and metals bound to mineral particles such as phytoplankton and organic matter (Lanceleur et al., 2011) and therefore represent good bioindicators of their environment (Gunther et al., 1999). A time series (1981-2013) of mature (2 year old) wildgrowing Crassostrea gigas Japanese oyster samples was extracted from the National Network for the Observation of Marine Environment Quality (RNO/ROCCH; i.e. the French MusselWatch; Ifremer.fr) specimen bank. Winter (February) oyster samples were chosen for the present work in order to avoid dilution of metal concentration due to variable soft-body weight during reproduction periods (Enríquez-Díaz et al., 2009). Individuals selected for this study originated from the mid-salinity range of the Gironde Estuary, at the La Fosse sampling site (salinity 15-20; Figure 1), where highest trace metal concentrations are recorded in the same set of oyster samples (e.g. Cd and Ag; Lanceleur et al., 2011). A pool of fifteen individuals for each winter have been selected, lyophilized and grinded. 


\subsection{Analytical Procedure}

Samples were ashed in quartz crucibles at $800^{\circ} \mathrm{C}$ during $3 \mathrm{~h}$ according to the heating scheme described by Nygren et al. (1990) and then digested using a mixture of $5 \mathrm{~mL}$ concentrated hydrochloric acid $\mathrm{HCl}$ and $3 \mathrm{~mL}$ of concentrated nitric acid $\mathrm{HNO}_{3}$ (both Suprapur ${ }^{\circledR}$, Merck) at $195^{\circ} \mathrm{C}$ for 4 hours. Then, samples were allowed to cool down, caps were removed and the acid was evaporated until near dryness. The residue was then redissolved adding $1 \mathrm{~mL}$ of concentrated sulphuric acid $\mathrm{H}_{2} \mathrm{SO}_{4}$ (TraceSELECT®, Fluka), and evaporated again until no fumes were observed (i.e. only $\mathrm{H}_{2} \mathrm{SO}_{4}$ was present). Cooled contents were then diluted with $0.1 \mathrm{M} \mathrm{HCl}$. Sediment samples were syringe-filtered using PFA syringes (Savillex ${ }^{\circledR}$ ) and $25 \mathrm{~mm}$ polyethersulfone membranes of $0.45 \mu \mathrm{m}$ pore size (VWR®) prior to analyses. Platinum measurements were carried out by means of catalytic adsorptive cathodic stripping voltammetry. Laboratory analyses were performed in a laminar flow bench (ISO-5) housed in an ISO-7 laboratory. Platinum voltammetric determinations were carried out using a $\mu$ Autolab Type III potentiostat (Metrohm ${ }^{\circledR}$ Autolab B.V.) connected to a polarographic stand (Metrohm ${ }^{\circledR} 663$ V.A.) equipped with three electrodes: i) a hanging mercury drop electrode (HMDE; the working electrode), ii) a $\mathrm{Ag} / \mathrm{AgCl}$ reference electrode, and iii) a glassy carbon auxiliary electrode. A polytetrafluoroethylene (PTFE) voltammetric cell served in all experiments and the potentiostat was controlled using the GPES v. 4.9 software (EcoChemie B.V.). Aliquots of $8 \mathrm{~mL}$ of acid-digested sample were pipetted into the voltammetric cell, and two reagents, $3.3 \mathrm{mM}$ formaldehyde (Riedelde-Haën), and $0.45 \mathrm{mM}$ hydrazine sulphate (Fluka) were added directly to the solution and allowed for the detection of Pt in the acidic media (see details in Cobelo-García et al., 2014b). Sample solution was first deaerated by 5 min of purging with humidified nitrogen (99.999\% ALPHAGAZ ${ }^{\text {TM }} 1$, Air Liquide $($ ). Accumulation on the HMDE was then initiated with a potential set up at $-0.3 \mathrm{~V}$ for $90 \mathrm{~s}$, while the solution was stirred at $3000 \mathrm{rpm}$ with a PTFE rod. After an equilibration time without stirring, a cathodic stripping scan was carried out by changing the potential from $-0.5 \mathrm{~V}$ to $-1.1 \mathrm{~V}$ in the differential pulse mode with a step potential of $4 \mathrm{mV}$, at a scan rate of $20 \mathrm{mV} . \mathrm{s}^{-1}$, a modulation time of $0.04 \mathrm{~s}$, an interval time of $0.2 \mathrm{~s}$, and a modulation amplitude of $25 \mathrm{mV}$. Before applying any derivative transformation, the original voltammogram was smoothed, with a smoothing factor of 2 and according to the Savitsky-Golay algorithm. The determination of Pt concentrations was achieved by standard addition method and the signal was processed by second derivative transformation (applied after data smoothing) as 
described in Cobelo-García et al., (2014b). The improvement in the peak detection and quantification applying the second derivative signal allows for the acquisition of a welldefined peak for Pt at low accumulation times. Second derivative was selected as it is more efficient in eliminating the background interferences than the first derivative, while keeping good peak-shaped transformed signals and better signal-to-noise ratio than higher derivative orders (Cobelo-García et al., 2014b).

For typical masses of $200 \mathrm{mg}$ for sediment and $40 \mathrm{mg}$ for biological samples the detection limits (calculated as three times the standard deviation of blank measurements) were $0.11 \mathrm{pmol} . \mathrm{g}^{-1}$ and $0.44 \mathrm{pmol} . \mathrm{g}^{-1}$, respectively. For sediments, accuracy was checked by the analysis of river sediment certified reference material (CRM; JSd-2; Geological Survey of Japan) with recoveries of $\sim 90 \%$ and precision (\% relative standard deviation; RSD) of about $5 \%(\mathrm{n}=3)$. Since no CRM existed for Pt in biological matrices, precision of the method was tested on certified dogfish muscle (DORM) resulting in low RSD between replicates of $~ 5 \%$ $(n=4)$.

Cadmium concentrations in oysters were measured by quadrupole ICP-MS (Inductively Coupled Plasma Mass Spectrometry) and typically differed by less than 15\% from the data provided by RNO/ROCCH for aliquots of the same samples analyzed by Graphite Furnace Atomic Absorption Spectrometry (Ifremer.fr). Cadmium and Thorium concentrations in sediment cores were also measured by ICP-MS (Audry et al., 2004a). Accuracy was checked by analysis of CRM (CRM 320; BCR). Recoveries were $~ 95 \%$ and precision was generally better than $5 \%$ for concentrations 10 times higher than detection limits. 


\section{RESULTS}

\subsection{Platinum and Cd concentrations in sediment cores}

Platinum concentrations in the Marcenac core samples were low and constant from the surface $(0.3 \mathrm{~cm})$ to the bottom $(122 \mathrm{~cm})$ of the core with a mean concentration of 1.07 pmol. $\mathrm{g}^{-1} \pm 0.39$ pmol.g ${ }^{-1}\left(\mathrm{n}=8\right.$; Figure $2 \mathrm{~A}$ ). With concentrations ranging from $\sim 1 \mathrm{pmol} . \mathrm{g}^{-1}$ to 7 pmol.g $\mathrm{g}^{-1}$, Cajarc sediments exhibit relatively high Pt concentration variations with values clearly higher than the concentrations in the Marcenac core until approximately $40 \mathrm{~cm}$ depth (Figure 2A). The maximum concentration occurred at the very bottom of the core, i.e. $123 \mathrm{~cm}$ depth representing about 10 times Marcenac core concentration. After displaying an almost flat profile with rather low and constant Pt concentrations between 40 and $6 \mathrm{~cm}$ depth, a positive anomaly can be observed at $4 \mathrm{~cm}$ depth. Platinum values finally almost reach Marcenac concentration in the topmost Cajarc sample ( $2 \mathrm{~cm}$ depth) exhibiting a minimal concentration of $0.88 \mathrm{pmol} . \mathrm{g}^{-1}$. Cadmium concentrations were taken from Audry et al. (2004a) and plotted together with Pt for comparison (Figure 2B). For detailed interpretation and age determination see Audry et al., (2004a). In most areas, hydraulic and mineralogical (chemical) particle fractionations result in increasing heavy metal concentrations with decreasing sediment grain sizes. It is therefore essential to normalize for grain size effects on natural, lithogenic trace metal variability before assessing anthropogenic inputs (Loring and Rantala, 1992). Thorium which is a conservative, lithogenic element in sedimentary cores (Krachler and Shotyk, 2004) and does not originate from any anthropogenic inputs in our study area served as a normalizing element. Several studies have used the particulate Th concentrations for the correction of grain size effects throughout the whole Lot-GaronneGironde fluvial-estuarine system (e.g. Coynel et al., 2007; Larrose et al., 2010). The Pt profile is smoothed by Th normalization, suggesting that grain size effects play a minor, but visible, role in the peak shape of the Pt record in the Cajarc core, i.e. Pt is predominantly enriched in the fine particles (Figure 2A). However, except from the attenuation of some peaks, normalized Pt profile displays the same positive anomalies as the original Pt concentration profile and confirms the Pt enrichment of Cajarc sediments compared to the Marcenac core. 


\subsection{Platinum and $\mathrm{Cd}$ concentrations in wild oysters}

Total Pt concentrations in oyster samples, expressed as pmol.g $\mathrm{g}^{-1}$ dry weight (dw) of oyster tissue, ranged from 0.80 to $3.1 \mathrm{pmol}^{-1}$ (Figure 3A). From 1981 to $2000, \mathrm{Pt}$ concentrations in oysters were constant with a mean value of $\sim 1.8$ pmol.g ${ }^{-1}\left( \pm 0.26 \mathrm{pmol} . \mathrm{g}^{-1}\right)$. Between 2001 and 2008, Pt concentrations increased to a maximum in 2006 being almost 2fold higher than the previous mean value. Following this peak, $\mathrm{Pt}$ concentrations decrease abruptly to a minimum of 0.80 pmol. $\mathrm{g}^{-1}$ in 2012 . The last measurement corresponding to the year 2013 displays however, a higher value, that reaches again the mean concentration of the 1981-2000 period.

Total $\mathrm{Cd}$ concentrations are expressed in $\mu \mathrm{mol} . \mathrm{g}^{-1} \mathrm{dw}$ of oyster tissue and ranges from 0.14 $\mu \mathrm{mol} . \mathrm{g}^{-1}$ to $1.3 \mu \mathrm{mol} . \mathrm{g}^{-1}$. The highest values occurred in the early $1980 \mathrm{~s}$ reflecting the highest industrial activity at the source, followed by an overall decreasing trend after the shutdown of the industrial $\mathrm{Zn}$ ore extraction in 1986 , from $\sim 0.95 \mu \mathrm{mol} . \mathrm{g}^{-1}$ in 1987 to $\sim 0.15 \mu \mathrm{mol} . \mathrm{g}^{-1}$ in 2013. These results obtained for pooled oysters from the national sample bank are very similar to those previously published by the RNO/ROCCH (Ifremer.fr) and by Lanceleur et al. 2011. 


\section{DISCUSSION}

\subsection{Past industrial Pt contamination in river sediments}

Considering the low values and the low variability of Marcenac sediment core $\mathrm{Pt}$ concentrations, The Marcenac sampling site may serve as a reference site for Pt pollution of the study area. Located upstream the industrial activity area, this site appears as not contaminated in numerous heavy metals such as $\mathrm{Zn}, \mathrm{Ag}, \mathrm{Cd}$ or $\mathrm{Pb}$, and is thus considered as a reference site for metal pollution of the Lot watershed in several previous studies (e.g. Lanceleur et al., 2011). Therefore, regional background Pt concentration, corresponding to mean Pt concentration of the Marcenac core, is of about 1.07 pmol.g ${ }^{-1}$. Reservoir sediments from the Lot River appear to be impoverished regarding Upper Continental Crust (UCC) Pt content (2.6 pmol.g ${ }^{-1}$; Rudnick and Gao, 2003), likely due to the geological composition of the Lot River watershed which mainly consists of Jurassic marine calcareous sedimentary rocks (Coynel et al., 2007). In such rocks, typical Pt concentrations are rather low, i.e., with typical concentrations lower than $2.6 \mathrm{pmol} . \mathrm{g}^{-1}$ and often around $1 \mathrm{pmol.g} \mathrm{g}^{-1}$ in ordinary chert beds (Hori et al., 2007). Marcenac Pt concentrations were also low compared to other estuarine or coastal systems such as pre-anthropogenic sediments from the Massachusetts Bay (3 pmol.g $\mathrm{g}^{-1}$; Tuit et al., 2000) or unpolluted Portuguese coastal sediments (2.9 pmol.g ${ }^{-1}$; Cobelo-García et al., 2011). The regional geochemical background for Pt in the Lot River watershed obtained from mean normalized Pt concentrations in the reference study site of Marcenac is $\mathrm{Pt} / \mathrm{Th} \sim 2.2 \times 10^{-5}$.

In order to assess the extent of $\mathrm{Pt}$ enrichment of Cajarc sediments compared to background natural values, the Enrichment Factors (EF) were calculated as follows:

$$
\mathrm{EF}=(\mathrm{Pt} / \mathrm{Th})_{\text {Cajarc }} /(\mathrm{Pt} / \mathrm{Th})_{\text {Marcenac }}
$$

Mean Pt/Th ratio of Marcenac sediments was selected as the background value instead of the crustal content in order to estimate the Riou-Mort River pollution impact. Enrichment factors were interpreted according to the scale established by Birth (2003) as detailed in Essien et al. (2009).

When comparing $\mathrm{Cd} / \mathrm{Th}$ and $\mathrm{Pt} / \mathrm{Th}$ profiles, positive anomalies occur at the same depths. This co-variation along the sediment core suggests a common source and transport of $\mathrm{Cd}$ and Pt metal inputs to the Lot River. Cadmium input variations in the Lot watershed were related to the history of the treatment of Zn-extraction residuals and were time-resolved according to 
radiochronology of ${ }^{137} \mathrm{Cs}$ (Audry et al., 2004a). Accordingly, the historical Pt records in Cajarc sediments also closely reflect the evolution of the industrial activity in the Decazeville basin. This includes changes in the treatment process of $\mathrm{Zn}$ residuals inducing variations of metal concentrations in river sediments. The bottom part of the core, dated from 1952, displays high Pt concentrations corresponding to moderate Pt enrichment. At that period, residuals were stocked as sludge and subject to leaching during rainfalls. Elevated $\mathrm{Pt} / \mathrm{Th}$ and $\mathrm{Cd} / \mathrm{Th}$ values at a depth of $42 \mathrm{~cm}$ co-occurred reflecting the accidental seepage of 1986 which was the major pollution event recorded in the reservoir sediments of the Lot River since the 1950s (Audry et al., 2004a). After this accidental event in 1986, Cd and Pt normalized profiles displayed a slight decrease and then constant, relatively low ratios, over $\sim 30 \mathrm{~cm}$ with $\mathrm{Pt} / \mathrm{Th}$ ratios close to the background value at the Marcenac sampling site $\left(\mathrm{Pt} / \mathrm{Th} \sim 1.5 \times 10^{-5}\right)$ and $\mathrm{Pt}$ EF showing an overall decreasing trend. For $\mathrm{Cd}$, this decrease was related to the cessation of Zn production in 1986 and subsequent remediation actions: treatment of groundwater tables and the containment of spoil tips by clay covering (Audry et al., 2004a). The recent decrease of both $\mathrm{Cd} / \mathrm{Th}$ and $\mathrm{Pt} / \mathrm{Th}$ towards background values suggests that the remediation of the Decazeville site successfully reduced $\mathrm{Cd}$ and $\mathrm{Pt}$ releases from the former industrial area. In this context, the early 1990's sediments indicate no enrichment in Pt with EF < 1.

Sediment cores already served as indicators of Pt pollution sources in other systems such as with an urban lake near Boston, Massachusetts. In these urban sediments the increasing Pt concentrations were clearly related to the introduction of automobile catalysts in the United States with Pt flux being approximately ten times higher than before and recent enrichment factors reaching 100 (calculated in the assumed absence of grain size influence; Rauch and Hemond, 2003). The influence of anthropogenic Pt emissions originating from car catalytic converters can be neglected in the Lot River sediment cores since no important urban area is located upstream from the sediment sampling sites and the population density at the Lot River watershed scale is very low ( 30 inhabitants $/ \mathrm{km}^{2}$; cartesfrance.fr) compared to that of the Bordeaux agglomeration ( 1000 inhabitants $/ \mathrm{km}^{2}$, cartesfrance.fr). However, as $\mathrm{Pt} / \mathrm{Th}$ in the upper sediments of both cores seem to slightly exceed the geochemical background value, we cannot exclude the existence of a slight signal of car converter-derived $\mathrm{Pt}$ in the uppermost Lot River sediment layers (Figure 2A). Such a signal would be consistent with recent works (2013 field campaign) establishing the Pt concentrations of surface Suspended Particulate Matter (SPM) from a Gironde Estuary tributary, the Garonne River, upstream (Port-SainteMarie sampling site) and downstream (La Réole sampling site; Figure 1) the Lot River confluence. Contemporary SPM displayed mean Th-normalized Pt values of $\sim 6.5 \times 10^{-5}$ 
(Cobelo-García et al., 2014a) which are considerably higher than the most recent values in the Cajarc sediment core. At these sampling sites, the Garonne River drains the atmospherically deposited Pt pollution originating from highly urbanized areas such as the Toulouse and Agen urban agglomerations. This diffuse source must account for Pt enrichment of the Garonne watershed. The Garonne river draining a basin comprising two important urban areas Toulouse and Bordeaux agglomerations (both more than 1 million inhabitants; Figure 1), is the main Gironde Estuary tributary. The Gironde Estuary is therefore submitted to anthropogenic pressure concerning automobile exhaust catalysts and Pt pollution.

\subsection{Post-1990 exponential increase of car catalytic converters}

As suspension feeder organisms, oysters, and especially the C.gigas species, have already served as bioindicators for trace metal contamination (e.g. Claisse et al., 1989). The Decazeville basin is known as the primary source of $\mathrm{Cd}$ in the Gironde watershed (Audry et al., 2004b), where chronic Cd pollution has led to the prohibition of bivalve production and consumption since 1996. Mass balances at the watershed scale showed that even 13-16 years after the termination of the $\mathrm{Zn}$ ore treatment (i.e. 1999-2002), the Decazeville basin contributed to more than $61 \%-92 \%$ of total Cd fluxes into the Gironde Estuary (Masson et al., 2006). This is further supported by i) historical records of $\mathrm{Cd}$ in estuarine freshwater sediments reflecting the industrial activity in the Decazeville watershed (Grousset et al., 1999) and ii) mass balances at the estuary scale, suggesting that intra-estuarine sources (e.g. the Bordeaux agglomeration) are negligible, compared to the main source (e.g. Schäfer et al., 2002).

Knowing the major source of $\mathrm{Cd}$ inputs to the system, the molar ratio between $\mathrm{Cd}$ and $\mathrm{Pt}$ served to determine Pt source of contamination. Cajarc sediments revealed a characteristic, relatively constant $\mathrm{Cd} / \mathrm{Pt}$ value close to $3 \times 10^{5}$ for the $\mathrm{Zn}$-ore treatment period from 1952 to 1978. During the mid-1980s and early 1990s, Cd/Pt molar ratios in Cajarc sediments were clearly higher and reached typical values of $\sim 7 \times 10^{5}$ suggesting that during the 1986 pollution accident and the following years, Cd release was extremely dominant. Although estuarine transformation and (bio)accumulation processes may be different, similar $\mathrm{Cd} / \mathrm{Pt}$ variations occurred in wild oysters where $\mathrm{Cd} / \mathrm{Pt}$ molar ratios were of about $3 \times 10^{5}$ in the early 1980s, and then increased from 1985 to 1989 to $\sim 5 \times 10^{5}$ which best characterizes the ultimate state of the Decazeville pollution source. These findings support the co-evolution 
trend of the two trace metals $\mathrm{Cd}$ and $\mathrm{Pt}$ in the Gironde wild oysters as observed in the Cajarc sediment core, and therefore, their common source and parallel transport along the fluvialestuarine system, i.e. from the industrial site to the coastal ocean. Given that industrial Pt demand was low before the 1990s (Johnson-Matthey, 2014), and in the absence of other reported Pt sources in the watershed, we assume that this ratio reflects the oyster response to the sum of Pt exclusively derived from both the natural sources and historic waste reservoirs of the Decazeville industry.

Based on $\mathrm{Cd} / \mathrm{Pt}$ molar ratios in oysters and assuming that during the whole observation period nearly all $\mathrm{Cd}$ in oysters was derived from the metal point source, we estimated respective theoretical Pt concentrations in oysters over time (Figure 3B). Before 1988, estimated and measured Pt concentrations were similar, which suggests that Pt in the oysters mostly derived from the industrial site. In contrast, increasing measured Pt concentrations and the gap appearing with estimated values after 1988 were attributed to increasing contributions by other sources (Figure 3B, dashed area). Platinum demand and use for the majority of application sectors in Europe was constant over time, (Johnson Matthey, 2014), resulting in relatively constant inputs from the watershed. However, recent Pt demand in Europe for autocatalysts is an exception. In fact, from 1981 to 1999, Pt demand for catalytic converters in Europe has increased by 30 times and from 1981 to 2007 even by 100 times (Figure 3C, Johnson Matthey, 2014). Despite the impossibility to access Pt emission data in France, European Pt demand for autocatalysts seems to be a good proxy for Pt use in catalytic converters and therefore Pt emissions. In this sector, Pt use is almost simultaneous with demand since cars are built and sold in a short period of time in answer to current demand. Furthermore, emission data show that the majority of Pt particle emissions occur during the first thousands kilometers of the car (Artelt et al., 1999) resulting in a short delay between Pt demand and Pt emission. The difference between measured $\mathrm{Pt}$ and estimated $\mathrm{Pt}$ (using $\mathrm{Cd} / \mathrm{Pt}$ molar ratios in oysters, Figure 3B, dashed area) seems to be correlated with the European $\mathrm{Pt}$ demand for car catalytic converters (since 1988; Figure 3C). These simulated Pt concentrations rise in oyster samples until reaching a maximum value in 2006. After which they decrease sharply, probably reflecting a break-down in Pt demand in many sectors due to difficult economic conditions during 2008-2010 (Johnson Matthey, 2010). In fact, the largest fall in automobile Pt demand occurred in Europe, where gross car catalytic converters Pt demand decreased on average by 50\% (Johnson Matthey, 2014). Recently, increasing Pt concentrations in oysters might result from a new strong European Pt demand for catalytic converters, which started to increase again since 2010 (Johnson Matthey, 2014). Increase in Pt 
emissions by cars is recorded by wild oysters, assuming a time-lag of 2-4 years. This response time can be explained by (i) transport time from the source to the estuary mouth $(\sim 400 \mathrm{~km})$, (ii) estuarine particle residence time ( 2 years; Jouanneau and Latouche, 1982), (iii) estuarine Pt transformation processes (Cobelo-García et al., 2014a) and (iv) the age of wild oysters at the sampling time (2 year old). As well as wild oysters, time-series analysis of mussels from an urban beach revealed excess (or anthropogenic) Pt related to its use in car catalytic converters and car sales in Spain and Portugal (Neira et al., 2015). Temporal trends of Pt accumulation in both wild oysters and mussels from urbanized aquatic system indicate the change in Pt use over time. Accordingly, the data suggest that, the historical metal pollution source in the Decazeville area was the major Pt source to the Gironde oysters in the past (before 1990), but that Pt emissions from cars have become increasingly dominant in the two past decades.

\subsection{Platinum bioconcentration in wild oysters}

Experimental studies showed that traffic-related $\mathrm{Pt}$ is uptaken by biota such as plants (e.g. Schäfer et al., 1998) or aquatic animals under different exposure pathways (e.g. water containing road dust; Zimmermann et al., 2002). Field studies analyzed Pt uptake of aquatic organisms such as isopods or amphipods (e.g. Rauch and Morrison, 1999, Haus et al., 2007), and more recently bivalves (e.g. Neira et al., 2015, Ruchter and Sures, 2015). In order to estimate the Pt uptake by wild oysters, bioconcentration factor (BCF) which refers to uptake of a chemical substance from water via respiratory surface and/or skin (Arnot and Gobas, 2006), was estimated as:

$$
\mathrm{BCF}=\mathrm{C}_{\mathrm{B}} / \mathrm{C}_{\mathrm{WD}}
$$

Where $C_{B}$ is the chemical concentration in the organism (mmol.kg ${ }^{-1}$ ) and $C_{W D}$ the freely dissolved chemical concentration in the water (nmol.L ${ }^{-1}$; Arnot and Gobas, 2006). We used dissolved Pt concentrations assuming that dissolved metals are generally potentially more bioavailable than their particulate forms (e.g. Lekhi et al., 2008). This statement is supported by preliminary results on $\mathrm{Pt}$ uptake pathways with the study of $\mathrm{Pt}$ organ distribution in $C$. gigas revealing higher Pt concentrations in gills (unpublished data) suggesting the dominance of direct contamination pathway, i.e. uptake by the gill epithelium of the dissolved metal from the water column. Maximal dissolved trace metal concentration served to calculate the BCF 
that is known as being the minimal estimation. This concentration was measured recently in the Gironde estuarine system at 0.62 pmol. $\mathrm{L}^{-1}$ in the mid-salinity range (Cobelo-García et al., 2014a). Considering 2013 mean Pt concentration in oysters from the La Fosse site of 1.7 pmol.g $\mathrm{g}^{-1}$, dw, minimum BCF is of about $3 \times 10^{3}$. Similar values $\left(\sim 5 \times 10^{3}\right)$ were observed in wild mussels from the Samil urban beach (Spain; Neira et al., 2015). In comparison, for Cd and $\mathrm{Ag}$ respective minimum $\mathrm{BCF}$ were estimated at $2 \times 10^{5}$ and $6 \times 10^{6}$ in the same system (Lanceleur et al., 2011) suggesting that bioconcentration of Pt in wild oysters is lower than for those two trace metals. A study on aquatic macroinvertebrates proved that, although $\mathrm{Pt}$ concentrations are relatively low in aquatic habitats, high bioconcentration factors, close to those of essential elements, can occur in biota (Haus et al., 2007). Thus, bioconcentration and uptake of trace metals depend on several factors including the feeding behavior of the organism or the trace metal speciation. For instance, Ruchter and Sures (2015) attributed the low concentrations of traffic related metals in clam tissues to the active avoidance of the soluble metal forms and particles in the water column. Furthermore, uptake mechanisms depend also on the Pt form present in the environment, $\mathrm{Pt}(\mathrm{IV})$ being more likely to be taken up at a higher rate than Pt(II) (Rauch and Morrison, 1999). The speciation and partitioning of $\mathrm{Pt}$ are highly dependent of the residence time of the metal in the water column (Cobelo-García et al., 2008) and Pt partitioning between the particulate and dissolved phase in the Gironde Estuary suggests complex behavior with no clear salinity dependence (Cobelo-García et al., 2014a). Discrepancies between measurements of Pt uptake in biota and other parameters such as the speciation and phase distribution might be related to a number of oversimplifications. More data are needed on Pt biogeochemical cycle, behavior and speciation since all those parameters vary according to the system. Thus, a recent comparison between current and 20 year old dissolved Pt concentration profiles show that anthropogenic Pt has little effect on dissolved Pt in the open oceans (Suzuki et al., 2014). Our study suggests that coastal waters are more affected by atmospherically-derived anthropogenic Pt.

Even though large Pt inputs must originate from car catalytic converters, other urban sources of Pt contamination should be considered. In fact surface waters draining hospital wastewaters which contain patient excretion of Pt-based anticancer drugs display $\mathrm{Pt}$ concentrations which could exceed natural inputs (Vyas et al., 2014). These drugs may have a significantly higher toxicological impact than catalyst-derived inorganic Pt (Lenz et al., 2007). Furthermore, recent works have revealed that particle adsorption, as well as, the reactivity of their respective degradation products decreased from river water to estuarine 
water (Turner and Mascorda, 2015), implying the need for further research on Pt species in coastal environments. 


\section{Conclusion and Perspectives}

Historical records of $\mathrm{Pt}$ in sediment cores and biota samples have allowed the identification of the continental sources that contribute to Pt pressure in the Gironde fluvialestuarine continuum. The results clearly show the succession of two major sources: a former point source originating from industrial activities in the Lot watershed and a recent diffuse source related to the exponentially increasing Pt use in vehicle catalytic converters. Data on Pt levels in wild oysters suggest that (i) Pt in estuaries is bioavailable to bivalves, (ii) oysters are suitable biomonitors of Pt contamination in the environment, and (iii) oysters from the Gironde Estuary have recorded the succession of different Pt sources in the Gironde watershed, covering the past $\sim 35$ years (1981-2013). The recent evolution and dominance of catalytic-converters-derived Pt recorded in wild oysters and the widespread use of this technology all over the world clearly suggest that other watersheds also undergo profound changes in their Pt budget. The forecast increase in population density in coastal areas (UN, 2007) will probably strongly enhance Pt pressure in coastal environments. Future research should account for Pt behavior and speciation in estuaries and other marine systems in order to accurately evaluate its bioavailability to marine organisms and the associated toxicity. All of this information would allow better assessment of potential Pt adverse effects on living organisms and ecosystems.

\section{Acknowledgements}

This work has benefited from support by the FEDER Aquitaine, the Agence de l'Eau AdourGaronne, the Marie Curie Individual Fellowship FP7-PEOPLE-2011-IEF \#302505 ISOGIRE, the COST Action TD1407, and the EU FP7 Ocean 2013.2 Project SCHeMA Project-Grant Agreement 614002 which are gratefully acknowledged. 


\section{References}

Arnot, J.A., Gobas, F.A.P.C., 2006. A review of bioconcentration factor (BCF) and bioaccumulation factor (BAF) assessments for organic chemicals in aquatic organisms. Environ. Rev. 14, 257-297.

Artelt, S., Kock, H., König, H.P., Levsen, K., Rosner, G., 1999. Engine dynamometer experiments: platinum emissions from differently aged three-way catalytic converters. Atmos. Environ. 33, 3559-3567.

Audry, S., Schäfer, J., Blanc, G., Jouanneau, J.-M., 2004a. Fifty-year sedimentary record of heavy metal pollution $(\mathrm{Cd}, \mathrm{Zn}, \mathrm{Cu}, \mathrm{Pb})$ in the Lot River reservoirs (France). Environ. Pollut. 132, 413-426.

Audry, S., Schäfer, J., Blanc, G., Bossy, C., Lavaux, G., 2004b. Anthropogenic components of heavy metal $(\mathrm{Cd}, \mathrm{Zn}, \mathrm{Cu}, \mathrm{Pb})$ budgets in the Lot-Garonne fluvial system (France). Appl. Geochem. 19, 769-786.

Barbante, C., Veysseyre, A., Ferrari, C., Van De Velde, K., Morel, C., Capodaglio, G., Cescon, P., Scarponi, G., Boutron, C., 2001. Greenland snow evidence of large scale atmospheric contamination for platinum, palladium, and rhodium. Environ. Sci. Technol. 35, 835-839.

Cartesfrance.fr, http://www.cartesfrance.fr/carte-france-departement/carte-departementLot.html (last accessed in 2015).

Claisse, D., 1989. Chemical contamination of French coasts. The results of a ten years mussel watch. Mar. Pollut. Bull. 20, 523-528.

Cobelo-García, A., Turner, A., Millward, G.E., 2008. Fractionation and reactivity of platinum group elements during estuarine mixing. Environ. Sci. Technol. 42, 1096-1101.

Cobelo-García, A., Neira, P., Mil-Homens, M., Caetano, M., 2011. Evaluation of the contamination of platinum in estuarine and coastal sediments (Tagus Estuary and Prodelta, Portugal). Mar. Pollut. Bull. 62, 646-650.

Cobelo-García, A., López-Sánchez, D.E., Schäfer, J., Petit, J.C.J., Blanc, G., Turner, A., 2014a. Behavior and fluxes of Pt in the macrotidal Gironde Estuary (SW France). Mar. Chem. 167, 93-101.

Cobelo-García, A., Santos-Echeandía, J., López-Sánchez, D.E., Almécija, C., Omanović, D., 2014b. Improving the voltammetric quantification of ill-defined peaks using second derivative signal transformation: example of the determination of platinum in water and sediments. Anal. Chem. 86, 2308-2313. 
Cobelo-García, A., Filella, M., Croot, P., Frazzoli, C., Du Laing, G., Ospina-Alvarez, N., Rauch, S., Salaun, P., Schäfer, J., Zimmermann, S., 2015. COST action TD1407: network on technology-critical elements (NOTICE) - from environmental processes to human health threats. Environ. Sci. Poll. Res. 22, 15188-15194.

Coynel, A., Schäfer, J., Blanc, G., Bossy, C., 2007. Scenario of particulate trace metal and metalloid transport during a major flood event inferred from transient geochemical signals. Appl. Geochem. 22, 821-836.

Enríquez-Díaz, M., Pouvreau, S., Chávez-Villalba J., Le Pennec, M., 2009. Gametogenesis, reproductive investment, and spawning behavior of the Pacific giant oyster Crassostrea gigas: evidence of an environment-dependent strategy. Aquacult. Int. 17, 491-506.

Essien, J.P., Antai, S.P., Olajire, A.A., 2009. Distribution, seasonal variations and ecotoxicological significance of heavy metals in sediments of cross river estuary mangrove swamp. Water, Air, Soil Pollut. 197, 91-105.

Grousset, F.E., Jouanneau, J.M., Castaing, P., Lavaux, G., Latouche, C.A., 1999. 70 year record of contamination from industrial activity along the Garonne River and its tributaries (SW France). Estuarine Coastal Shelf Sci. 48, 401-414.

Gunther, A.J., Davis, J.A., Hardin, D.D., Gold, J., Bell, D., Crick, J.R., Scelfo, G.M., Sericano, J., Stephenson, M., 1999. Long-term bioaccumulation monitoring with transplanted bivalves in the San Francisco Estuary. Mar. Pollut. Bull., 38, 170-181.

Haus, N., Zimmermann, S., Wiegand, J., Sures, B., 2007. Occurrence of platinum and additional traffic related heavy metals in sediments and biota. Chemosphere 66, 619-629.

Hori, R.S., Fujiki, T., Inoue, E., Kimura, J.I., 2007. Platinum group element anomalies and bioevents in the Triassic-Jurassic deep-sea sediments of Panthalassa. Palaeogeogr. Palaeoclimatol. Palaeoecol. 244, 391-406.

Ifremer.fr, www.ifremer.fr/deltn/pages/rno.htm (last accessed in 2015).

Johnson Matthey, 2010. Platinum 2010 Review. Johnson Matthey PLC, pp. 1-64.

Johnson Matthey, 2014. http://www.platinum.matthey.com/services/market-research/marketdata-tables. Johnson Matthey PLC (last accessed in 2015).

Jouanneau, J.M., Latouche, C., 1982. Estimation of fluxes to the ocean from mega-tidal estuaries under moderate climates and the problems they present. Hydrobiologia 91, 23-29.

Krachler, M., Shotyk, W., 2004. Natural and anthropogenic enrichments of molybdenum, thorium, and uranium in a complete peat bog profile, Jura Mountains, Switzerland. J. Environ. Monit. 6, 418-426. 
Lanceleur, L., Schäfer, J., Chiffoleau, J.-F., Blanc, G., Auger, D., Renault, S., Baudrimont, M., Audry, S., 2011. Long-term records of cadmium and silver contamination in sediments and oysters from the Gironde fluvial-estuarine continuum - Evidence of changing silver sources. Chemosphere 85, 1299-1305.

Larrose, A., Coynel, A., Schäfer, J., Blanc, G., Massé, L., Maneux, E., 2010. Assessing the current state of the Gironde Estuary by mapping priority contaminant distribution and risk potential in surface sediment. Appl. Geochem. 25, 1912-1923.

Lekhi, P., Cassis, D., Pearce, C.M., Ebell, N., Maldonado, M.T., Orians, K.J., 2008. Role of dissolved and particulate cadmium in the accumulation of cadmium in cultured oysters (Crassostrea gigas). Sci. Total Environ. 393, 309-325.

Lenz, K., Koellensperger, G., Hann, S., Weissenbacher, N., Mahnik, S.N., Fuerhacker, M., 2007. Fate of cancerostatic platinum compounds in biological wastewater treatment of hospital effluents. Chemosphere 69, 1765-1774.

Loring, D.H., Rantala, R.T.T., 1992. Manual for the geochemical analyses of marine sediments and suspended particulate matter. Earth-Sci. Rev. 32, 235-283.

Masson, M., Blanc, G., Schäfer, J., 2006. Geochemical signals and source contributions to heavy metal $(\mathrm{Cd}, \mathrm{Zn}, \mathrm{Pb}, \mathrm{Cu})$ fluxes into the Gironde Estuary via its major tributaries. Sci. Total Environ. 370, 133-146.

Neira, P., Cobelo-García, A., Besada, V., Santos-Echeandía, J., Bellas, J., 2015. Evidence of increased anthropogenic emissions of platinum: Time-series analysis of mussels (1991-2011) of an urban beach. Sci. Total Environ. 514, 366-370.

Nygren, O., Vaughan, G.T., Florence, T.M., Morrison, G.M.P., Warner, I.M., Dale, L.S., 1990. Determination of platinum in blood by adsorptive voltammetry. Anal. Chem. 62, 16371640 .

Pawlak, J., Lodyga-Chruścińska, E., Chrustowicz, J., 2014. Fate of platinum metals in the environment. J. Trace Elem. Med. Biol. 28, 247-254.

Rauch, S., Morrison, G.M., 1999. Platinum uptake by the freshwater isopod Asellus aquaticus in urban rivers. Sci. Total Environ. 235, 261-268.

Rauch, S., Hemond, H.F., 2003. Sediment-based evidence of platinum concentration changes in an urban lake near Boston, Massachusetts. Environ. Sci. Technol. 37, 3283-3288.

Reith, F., Campbell, S.G., Ball, A.S., Pringe, A., Southam, G., 2014. Platinum in Earth surface environments. Earth-Sci. Rev. 131, 1-21. 
Rodrigues, S.M., Glegg, G.A., Pereira, M.E., Duarte, A.C., 2009. Pollution problems in the northeast Atlantic: lessons learned for emerging pollutants such as the platinum group elements. Ambio 38, 17-23.

Ruchter, N., Sures, B., 2015. Distribution of platinum and other traffic related metals in sediments and clams (Corbicula sp.). Water Res. 313-324.

Rudnick, R.L., Gao, S., 2003. Composition of the continental crust, in: Holland, H.D., Turekian, K.K. (Eds.), Treatise on Geochemistry, Elsevier, Oxford, pp 1-64.

Schäfer, J., Hannker, D., Eckhardt, J.-D., Stüben, D., 1998. Uptake of traffic-related heavy metals and platinum group elements (PGE) by plants. Sci. Total Environ. 215, 59-67.

Schäfer, J., Eckhardt, J.D., Berner, Z.A., Stüben, D., 1999. Time-dependent increase of traffic-emitted platinum-group elements (PGE) in different environmental compartments. Environ. Sci. Technol., 33, 3166-3170.

Schäfer, J., Blanc, G., Lapaquellerie, Y., Maillet, N., Maneux, E., Etcheber, H., 2002. Tenyear observation of the Gironde tributary fluvial system: Fluxes of suspended matter, particulate organic carbon and cadmium. Mar. Chem. 79, 229-242.

Sen, I. S., Peucker-Ehrenbrink, B., 2012. Anthropogenic disturbance of element cycles at the Earth's surface. Environ. Sci. Technol. 46, 8601-8609.

Soyol-Erdene, T.O., Huh, Y., Hong, S., Hur, S.D., 2011. A 50-year record of platinum, iridium, and rhodium in Antarctic snow: volcanic and anthropogenic sources. Environ. Sci. Technol. 45, 5929-5935.

Suzuki, A., Obata, H., Okubo, A., Gamo, T., 2014. Precise determination of dissolved platinum in seawater of the Japan Sea, Sea of Okhotsk and western North Pacific Ocean. Mar. Chem. 166, 114-121.

Tuit, C.B., Ravizza, G.E., Bothner, M.H., 2000. Anthropogenic platinum and palladium in the sediments of Boston Harbor. Environ. Sci. Technol. 34, 927-932.

Turner, A., Mascorda, L., 2015. Particle-water interactions of platinum-based anticancer drugs in river water and estuarine water. Chemosphere 119, 415-422.

United Nations (UN) Population Division, 2007. World Urbanization Prospects: The 2007 Revision. U.N. New York.

Vyas, N., Turner, A., Sewell, G., 2014. Platinum-based anticancer drugs in waste waters of a major UK hospital and predicted concentrations in recipient surface waters. Sci. Total Environ. 493, 324-329. 
Zereini, F., Skerstupp, B., Alt, F., Helmers, E., Urban, H., 1997. Geochemical behaviour of platinum-group elements (PGE) in particulate emissions by automobile exhaust catalysts: experimental results and environmental investigations. Sci. Total Environ. 206, 137-146.

Zimmermann, S., Alt, F., Messerschmidt, J., Von Bohlen, A., Taraschewski, H., Sures, B., 2002. Biological availability of traffic-related platinum-group elements (palladium, platinum, and rhodium) and other metals to the zebra mussel (Dreissena polymorpha) in water containing road dust. Environ. Toxicol. Chem. 21, 2713-2718. 


\section{Figure captions}

Figure 1: The Gironde fluvial-estuarine continuum (SW France) with sampling locations: Oyster samples were collected in the Gironde Estuary mouth at La Fosse (diamond) and sediment cores were retrieved in the Lot River in Cajarc and Marcenac (triangles). Suspended Particulate Matter (SPM) samples were collected in the Garonne River at the La Réole and Port Sainte Marie sites and analyzed in a previous study (round symbols, Cobelo-García et al., 2014a).

Figure 2: Depth profiles of $\mathrm{Pt}$ and $\mathrm{Cd}$ concentrations and normalized concentrations in sediment cores from the Lot River. Sediment cores were collected in the Marcenac (empty symbols; upstream the potential pollution source) and Cajarc (filled symbols; downstream the potential pollution source) sampling sites. Platinum concentrations (A, pmol.g ${ }^{-1}$, diamonds) and $\mathrm{Cd}$ concentrations (B, $\mu \mathrm{mol} . \mathrm{g}^{-1}$, round symbols) are represented. Grain size effects were corrected by Thorium concentrations and $\mathrm{Pt} / \mathrm{Th}\left(\mathrm{A}, \mathrm{x} 10^{-5}\right.$, triangles) and $\mathrm{Cd} / \mathrm{Th}(\mathrm{B}$, squares) depth profiles give normalized concentrations. Thorium and $\mathrm{Cd}$ concentrations, and the estimated timescale (based on ${ }^{137} \mathrm{Cs}$ profile) are from Audry et al., (2004a).

Figure 3: Time variations of $\mathrm{Pt}$ and $\mathrm{Cd}$ concentrations in wild oysters from the La Fosse sampling site at the Gironde Estuary mouth. (A) Platinum (pmol.g ${ }^{-1}$, diamonds) and $\mathrm{Cd}$ ( $\mu \mathrm{mol.g} \mathrm{g}^{-1}$, squares) concentrations measured in winter oysters collected from 1981 to 2013. (B) Platinum concentrations measured (pmol.g ${ }^{-1}$, filled diamonds) and estimated (pmol.g ${ }^{-1}$, empty diamonds) from $\mathrm{Cd} / \mathrm{Pt}$ molar ratios and $\mathrm{Cd}$ concentrations measured in wild oysters. The dashed area corresponds to the lag between measured and estimated Pt concentrations. (C) Platinum concentrations (pmol.g ${ }^{-1}$,dark line) originating from the difference between measured and estimated Pt concentrations (B, dashed area) and European Pt demand for car catalytic converters (metric tons, bars, after Johnson Matthey, 2014). 


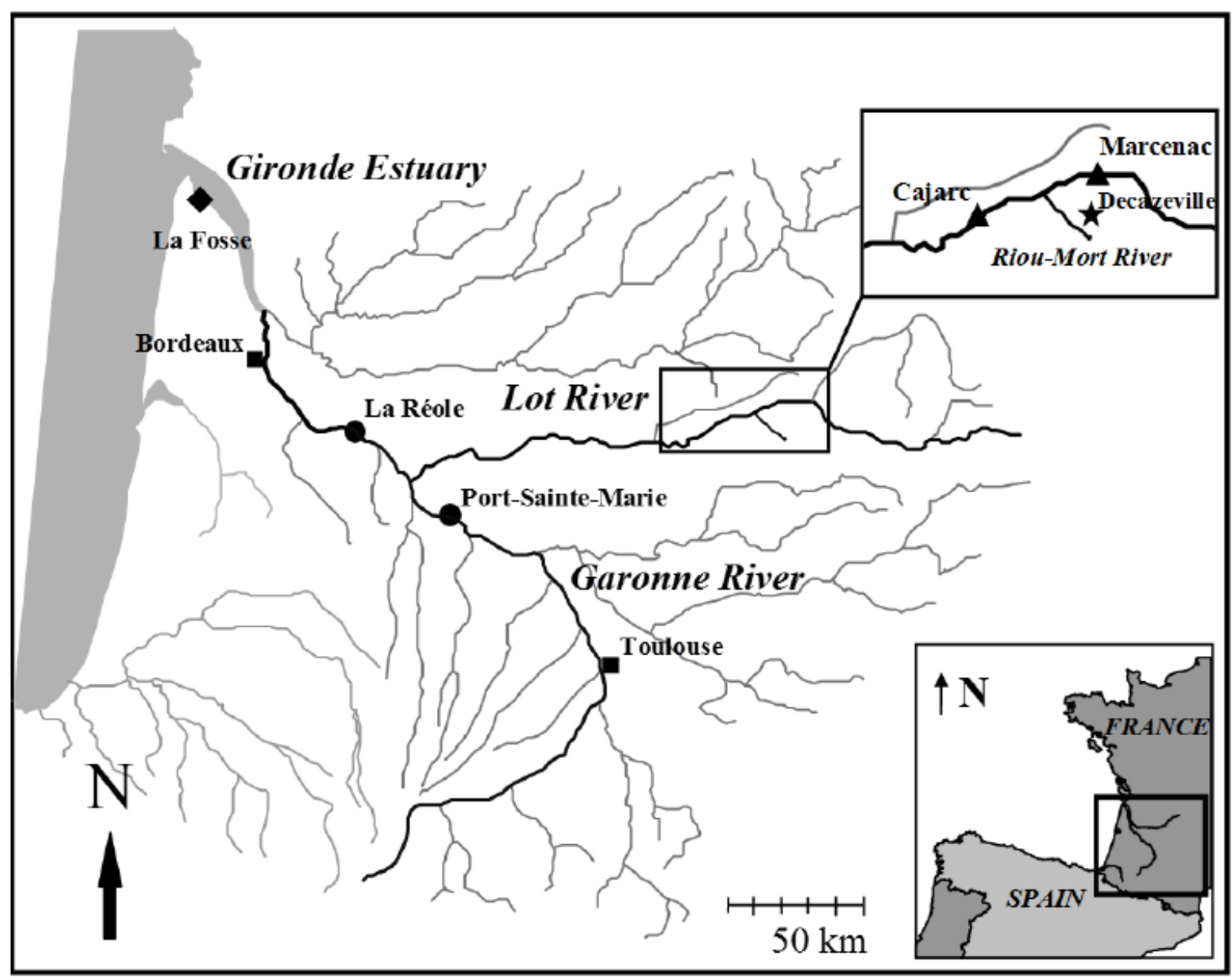

Figure 1 


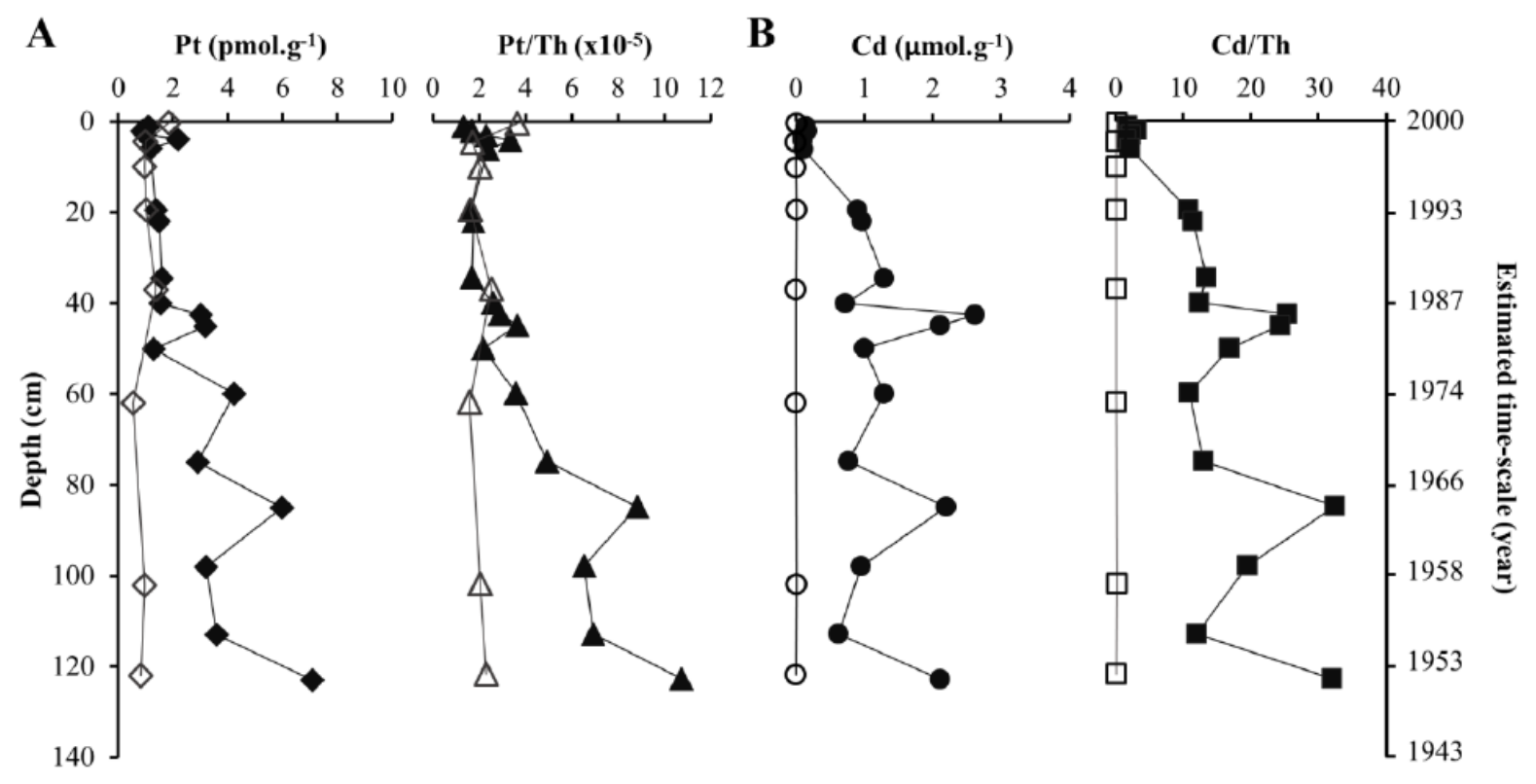

Fugure 2 


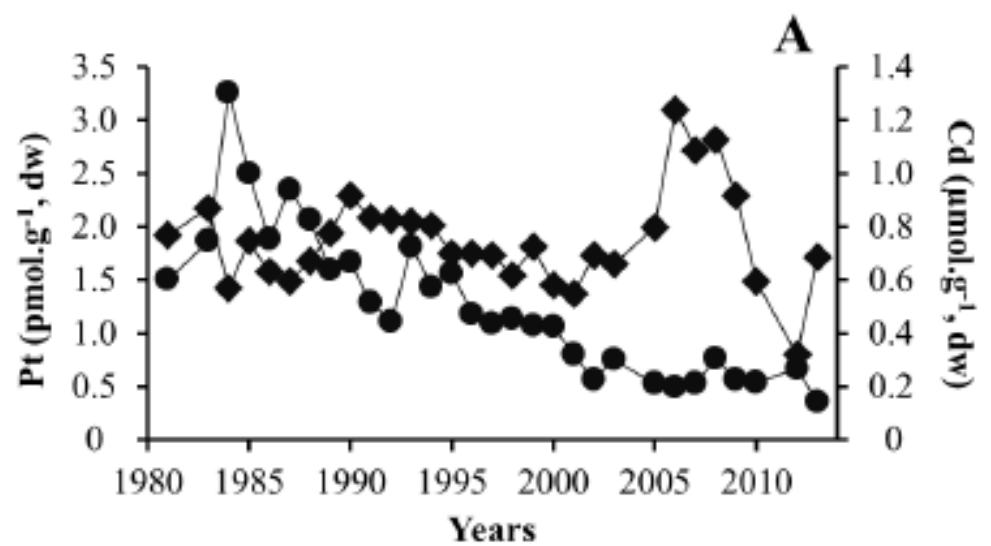

B
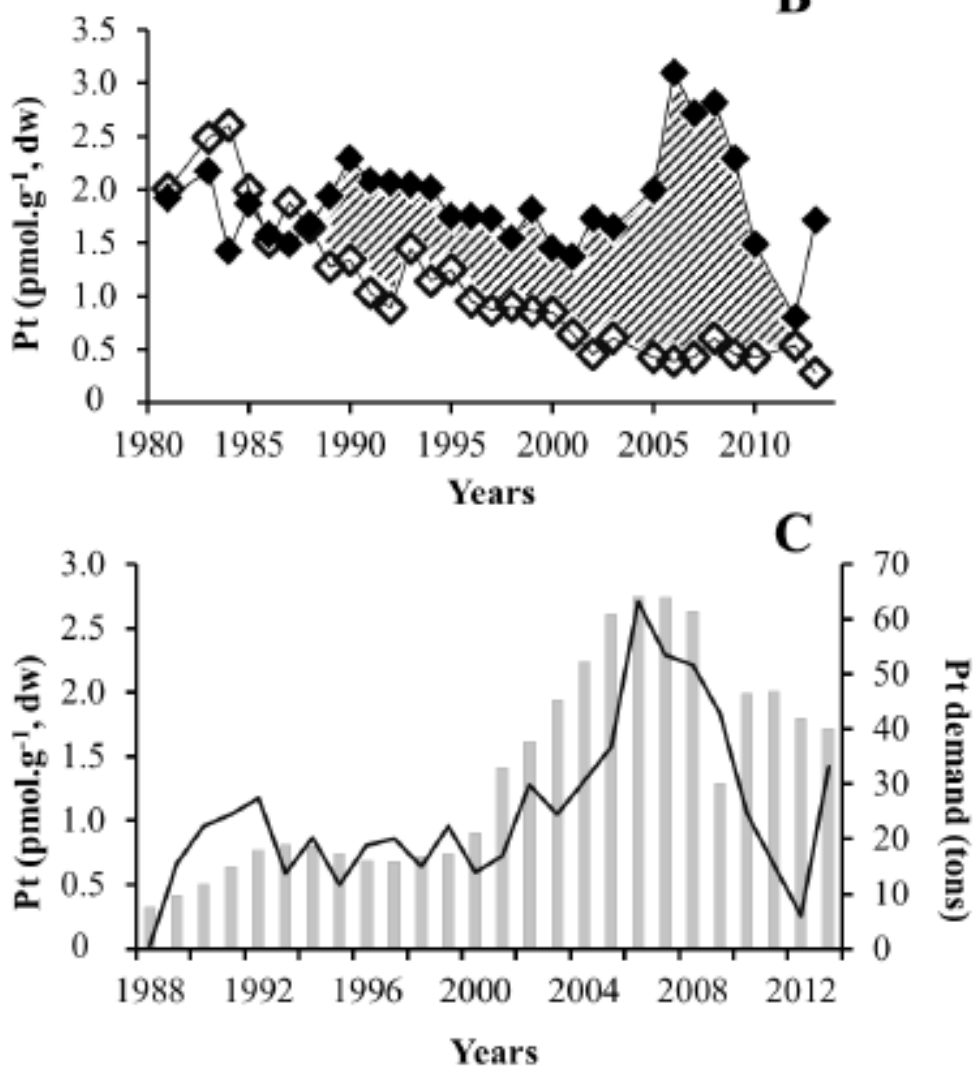

Figure 3 


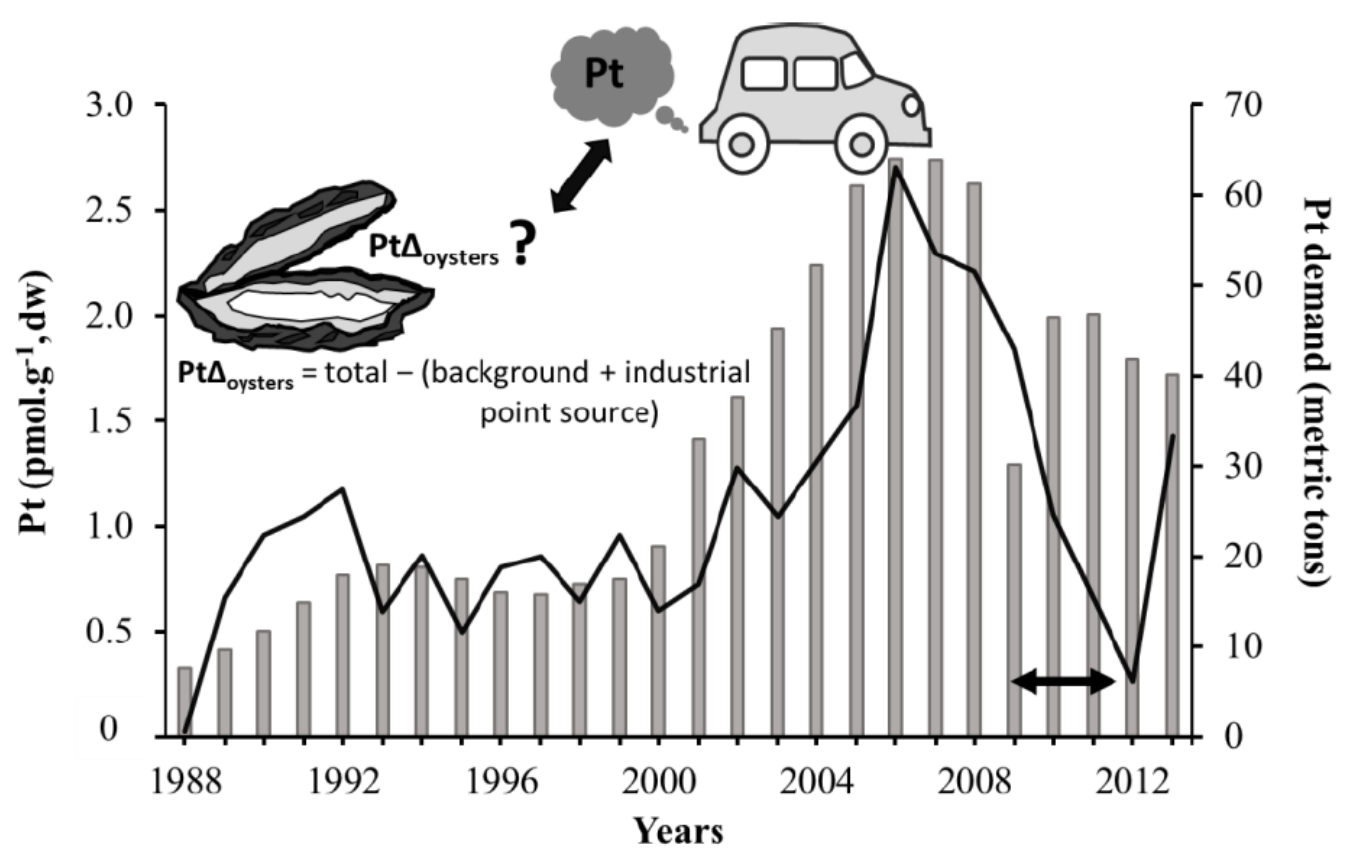

Graphical abstract 